\title{
EFEKTIVITAS KOMUNIKASI VIRTUAL PEMBELAJARAN DARING DALAM MASA PSBB (Studi Kasus Pembelajaran Jarak Jauh Produktif Siswa SMK Negeri 2 Banjarmasin)
}

\author{
Shen Shadiqien \\ Universitas Islam Kalimantan Muhammad Arsyad Al-Banjari Banjarmasin \\ e-mail: shen2705@gmail.com
}

\begin{abstract}
ABSTRAK
Pemberlakuan pembelajaran jarak jauh karena pandemi wabah COVID-19 dan pembelakuan pembatasan sosial berskala besar atau PSBB di Kota Banjarmasin mengakibatkan salah satu institusi yaitu institusi pendidikan mewajibkan pelaksanaan kegiatan kerja dan pembelajaran secara jarak jauh dengan menggunakan teknologi internet bagi guru dan siswa peserta pembelajaran. Penggunaan instrumen aplikasi video teleconference dalam pembelajaran dianggap lebih mendekati mewakili proses interaksi pembelajaran secara persuasif oleh pengajar terhadap peserta didiknya dengan komunikasi virtual melalui fasilitas teknologi internet dengan video teleconference. Namun salah satu ciri dari pembelajaran jarak jauh adalah terpisahnya antara pengajar dan siswa baik secara ruang dan waktu sehingga membutuhkan perencanaan yang sistematis dan terdiri dari persiapan, dan presentasi bahan ajar, pengawasan dan dukungan pembelajaran siswa, yang dicapai dengan menjembatani jarak fisik antara siswa dan guru melalui media teknis yang tepat. Fakta di lapangan pembelajaran daring secara video teleconference sering tidak terpenuhi sesuai jumlah rombongan belajar dalam satu kelas, sehingga masalah tersebut menjadi kendala dalam melakukan penilaian secara menyeluruh oleh guru terhadap siswa dalam satu rombongan belajar. Meninjau permasalahan tersebut, perlu untuk mengetahui dampak komunikasi virtual dalam pembelajaran daring, menelusuri kendala dan permasalahan secara teknis yang dilaksanakan menggunakan teknologi komunikasi virtual jarak jauh secara realtime atau non-realtime serta mengidentifikasi pola-pola pembelajaran yang sesuai dan tepat sesuai kondisi siswa
\end{abstract}

Kata kunci : Pembelajaran Daring;Komunikasi Virtual.

\section{LATAR BELAKANG}

Pemberlakuan Pembelajaran Jarak Jauh karena Pandemi Wabah COVID-19 dan

Pembelakuan Pembatasan Sosial Berskala Besar atau PSBB di Kota Banjarmasin oleh Pemerintah Daerah mengakibatkan institusi-institusi tertentu, diantaranya adalah institusi pendidikan, diwajibkan melaksanakan kegiatan kerja dan pembelajaran secara jarak jauh dengan menggunakan teknologi internet bagi guru dan siswa peserta pembelajaran.

Dari sekian banyak cara dalam melaksanakan pembelajaran secara jarak jauh, salah satu cara penerapan Pembelajaran Daring adalah dilakukan secara Komunikasi Video Streaming, yaitu sebuah cara komunikasi melalui fasilitas teknologi internet dengan melakukan pertemuan tidak langsung yang secara virtual berinteraksi menggunakan applikasi flatform video teleconference yang dapat digunakan untuk peserta yang lebih dari dua orang secara realtime atau dalam satu waktu yang serempak. Aplikasi video teleconference antara lain adalah ; Google Meet, Microsoft Team, Cisco Webex, Skype dan Zoom.

Teknologi Video Content, Video Teleconference mau pun Video Call Streaming sebagai sebagai salah satu fasilitas dalam melaksanakan Pembelajaran Jarak Jauh dengan Komunikasi Virtual yang mampu berinteraksi secara tidak langsung antara Guru dan Siswa menjadi sangat dibutuhkan dan bermanfaat dalam bidang pendidikan dan komunikasi, tidak hanya dalam masa isolasi dari pandemi wabah COVID-19, tetapi juga dalam beberapa masa ke depan yang tidak membutuhkan 
keberadaan orang pada satu tempat di waktu yang sama untuk berinteraksi.

Dalam prosesnya di lapangan, walau pun banyak metode pembelajaran jarak jauh, guru-guru sekolah maupunpengajar institusi pendidikan lainnya lebih cenderung menggunakan instrumen aplikasi video teleconference karena interaksi dalam pembelajaran dianggap dapat terwakili oleh komunikasi virtual melalui fasilitas teknologi internet dengan video teleconference. Namun jumlah siswa yang mengikuti Pembelajaran Dalam jaringan atau Daring secara video teleconference sering tidak terpenuhi sesuai jumlah rombongan belajar dalam satu kelas, sehingga masalah tersebut menjadi kendala dalam melakukan penilaian secara menyeluruh oleh guru terhadap siswa dalam satu rombongan belajar.

Perlunya pemantauan terhadap pelaksanaan Pembelajaran Daring yang dilakukan secara Komunikasi Virtual untuk dapat mengetahui sejauh mana pengaruh metode pembelajaran tersebut terhadap perkembangan belajar siswa yang diharuskan belajar dari rumah dari sisi kualitas dan motivasinya. Serta diperlukan kajian analisa yang empiris terhadap potensial kreatifitas yang bisa ditumbuhkan dalam metode Pembelajaran Daring yang dilakukan secara Komunikasi Virtual dengan pola-pola yang terencana dan terkonsep, khususnya pada Pembelajaran mata pelajaran Produktif di Sekolah Menengah Kejuruan Negeri 2 Banjarmasin.

\section{TINJAUAN PUSTAKA}

Sebagai sebuah kajian ilmiah, penelitian terhadap Efektivitas Komunikasi Virtual Pembelajaran Daring terhadap Siswa Sekolah SMK Negeri 2 Banjarmasin dalam Masa PSBB Kota Banjarmasin dilandasi dengan Teori Pembelajaran Jarak Jauh dan Teori
Pembelajaran Efektif dari perspektif Teori Komunikasi Efektif.

\section{Teori Komunikasi Efektif}

Komunikasi Efektif adalah sebuah cara dalam berkomunikasi yang bertujuan untuk mendapatkan hasil feedback berupa perubahan sikap dari lawan komunikasi yang diharapkan terjadi pada proses atau setelah proses komunikasi berlangsung. Dalam prakteknya proses komunikasi efektif harus dilakukan melalui unsur-unsur komunikasi dengan menggunakan bahasa yang jelas dan bisa dipahami dengan mudah oleh orang lain.

Menurut Mc. Crosky Larson dan Knapp, komunikasi yang efektif dapat dicapai dengan mengusahakan ketepatan (accuracy) yang paling tinggi derajatnya antara komunikator dan komunikan dalam proses komunikasi. Komunikasi yang efektif hanya dapat terjadi jika komunikator dan komunikan memiliki persamaan dalam pengertian, sikap dan bahasa. Sebuah komunikasi dikatakan efektif apabila:

a. Pesan dapat diterima, dimengerti dan dipahami sesuai maksud pengirimnya.

b. Pesan yang disampaikan disetujui penerima dan ditindaklanjuti dengan perbuatannya.

c. Tidak ada hambatan berarti bagi penerima pesan untuk menindaklanjuti dengan perbuatan.

\section{Konsep Pembelajaran Jarak Jauh}

Dikenal dengan istilah Distance Learning atau Distance Education, yaitu Konsep Pembelajaran Jarak Jauh yang merupakan suatu sistem pendidikan dengan dilaksanakan secara terpisah antara pengajar dan siswa baik secara ruang dan waktu. Pertama kali "Distance learning" dikembangkan di Amerika Serikat, Perancis, Jerman, dan Inggris pada pertengahan abad 19, oleh 
Sir Isac Pitman, pada tahun 1840, mengajar jarak jauh dengan menggunakan surat.

Bagi Hilary Perraton (1988), pendidikan jarak jauh adalah proses pendidikan dimana proporsi pengajaran yang signifikan dilakukan oleh seseorang pengajar yang terpisah oleh ruang dan atau waktu dari pelajar.

Rudolf Manfred Delling (1985), menyatakan Pembelajaran Jarak Jauh secara umum adalah berupa kegiatan yang terencana dan sistematis dan terdiri dari didaktik persiapan, dan presentasi bahan ajar, pengawasan dan dukungan pembelajaran siswa, yang dicapai dengan menjembatani jarak fisik antara siswa dan guru melalui media teknis yang tepat.

Michael Moore (2013), juga menyatakan Pembelajaran Jarak Jauh sebagai bagian dari metode pembelajaran dimana perilaku mengajar dieksekusi terpisah dari perilaku belajar, termasuk yang dilakukan di hadapan peserta didik,sehingga komunikasi antar guru dan guru dengan pelajar harus difasilitasi dengan alat cetak, elektronik, mekanik, atau lainnya.

Dari banyak konsep sistem pembelajaran jarak jauh yang dikembangkan, yang pada dasarnya konsep pembelajaran ini dibagi menjadi dua kategori, yaitu; Sistem Berbasis Video dan Sistem Berbasis Data.

\section{a. Sistem Berbasis Video}

Sistem berbasis video pada dasarnya merupakan dampak dari meluasnya teknologi penyiaran televisi. Pembelajaran Jarak Jauh dengan sistem ini dilakukan dengan merekam materi belajar ke dalam kaset video dan diputar pada stasiun-stasiun televisi. Dengan jangkauan geografis yang cukup besar sasaran-sasaran siswa yang berada di pelosok yang masuk dalam cakupan siar akan mendapatkan manfaat konsep pembelajaran dengan sistem ini. Kekurangan dari sistem ini adalah kurangnya interaksi dan komunikasi dua arah antara pengajar dan peserta.

\section{b. Sistem Berbasis Data}

Sistem berbasis data merupakan interaksi informasi data menggunakan perangkat teknologi berbasis digital dan terhubung secara jaringan yang dapat diklasifikasikan dalam dua kategori: groupware dan internet.

\section{- Groupware}

Pada groupware, komunikasi data dengan perangkat lunak pada kategori computersupported coorperative (CSCW) melalui perangkat lunak seperti electronic messaging, data conferencing, dan messaging gateways. Aplikasi komputer pada goupware ini untuk sistem pembelajaran jarak jauh dibedakan menjadi empat kategori:

1. Computer Assisted Instruction (CAI) ; yaitu menggunaan komputer sebagai media pengajar untuk latihan dan praktek, tutorial, simulasi dan game, dan pemecah masalah (problem solving).

2. Computer Managed Instruction (CMI); yaitu menggunakan penyimpanan komputer, dan mempunyai kemampuan untuk mengorganisasi perintah dan aktivitas murid dan hasil kemajuan (progress). 
3. Computer Mediated Communication (CMC) ; yaitu menggunakan aplikasi komputer sebagai fasilitas komunikasi, seperti electronic mail, computer confrencing, dan bulletin board.

4. Computer - Based Multimedia (CBM); adalah penggunaan aplikasi komputer yang terintegrasi dengan berbagai macam sistem video, voice, dan teknologi komputer dalam satu sistem yang langsung dapat dikirim dan diakses dengan mudah.

\section{- Internet}

Internet atau portmanteau dari interconnected network adalah merupakan sistem jaringan komputer yang saling terhubung secara global dengan menggunakan protokol internet (TCP/IP) untuk menghubungkan antar perangkat di seluruh dunia.

Semenjak Internet berkembang sangat cepat sekali pada tahun 1990-an, bermunculan berbagai website yang menjadi media yang menarikdari tampilan dan content yang kompleks. Sistem ini menggunakan layananlayanan standar seperti World Wide Web (WWW), File Transfer Protokol (FTP), dan lain sebagainya yang berbasis pada protokol TCP/IP ( Transfer Control Protokol/Internet Protokol).

Namun kemajuan teknologi komputer yang lebih komprehensif sekarang memungkinkan menjadikan semua aplikasi yang dibutuhkan baik informasi berupa data, video dan suara dalam sistem groupware bisa didapatkan dalam satu perangkat dengan koneksi Internet.

\section{Pembelajaran Efektif}

Pembelajaran Efektif adalah merupakan suatu proses pembelajaran yang bisa memungkinkan peserta didik untuk belajar secara menyenangkan baik dari aspek ketrampilan, aspek pengetahuan, maupun aspek sikap. Sehingga secara efektif pembelajaran tersebut akan bermanfaat menumbuhkan kemampuan ketrampilan, nilai konsep dan bagaimana hidup serasi dengan sesama pada murid dari hasil belajarnya.

Secara teori menurut Reiser Robert (1996), bahwa pembelajaran efektif adalah pembelajaran dimana siswa memperoleh keterampilanketerampilan yang spesifik, pengetahuan dan sikap serta merupakan pembelajaran yang disenangi siswa. Intinya bahwa pembelajaran dikatakan efektif apabila terjadi perubahan-perubahan pada aspek kognitif, afektif, dan psikomotor.

Oleh Reigeluth \& Merril (1989), secara fakta konsep Pembelajaran Efektif memiliki ciri-ciri keberhasilan namun dengan kriteria tertentu, yaitu ;

a. Ciri-ciri:

- Aktif bukan pasif

- Kovert bukan overt

- Kompleks bukan sederhana

- Dipengaruhi perbedaan individual siswa

- Dipengaruhi oleh berbagai konteks belajar

\section{b. Kriteria :}

- Kecermatan penguasaan

- Kecepatan unjuk kerja

- Tingkat alih belajar

- Tingkat retensi 
Sehingga Joan Midden-fort dalam Soekartawi memberikan saran kepada institusi pendidikan dengan guru-guru atau tenaga pengajarnya yang ingin meningkatkan efektivitas proses belajar mengajar harus menyiapkan beberapa hal, yaitu :

a. Menyiapkan segala sesuatunya dengan baik

b. Buat motivasi di kelas

c. Tumbuhkan dinamika dan enthuism dalam diri pengajar

d. Menciptakan kesempatan untuk berkomunikasi dengan siswa

e. Perbaiki terus isi atau kualitas bahan ajar

\section{Motivasi Belajar}

Motivasi adalah sebuah dorongan keinginan yang kuat dari dalam diri seseorang dalam melakukan sesuatu dengan alasan dan tujuan tertentu yang menjadi pemicu dan alasannya. Motivasi diperlukan untuk membantu seseorang dalam mencapai keberhasilan dari melakukan atau melaksanakan suatu kegiatan, baik dengan atau pun tanpa tenggat waktu. Bagi seorang siswa atau pelajar biasanya cukup sulit untuk memiliki motivasi tertentu dalam melaksanakan proses belajar secara baik. Hal tersebut terjadi karena siswa yang masih dalam umur tanggungan orang tuanya cenderung akan merasa nyaman dengan kasih sayang dan kecukupan hidup yang diberikan orang tuanya sehari-hari.

Berbeda dengan siswa yang dalam keterbatasan, khususnya masalah ekonomi dalam keluarga. Siswa yang merasa mengalami keterbatasan akan memiliki alasan sebagai motivasi yang kuat untuk dapat mencapai keberhasilan termasuk keberhasilan dalam belajar dengan tujuan dapat keluar dari permasalahan ekonomi yang dihadapinya dan keluarga.

Menurut Wlodkowski (1985), bahwa Motivasi adalah suatu kondisi yang menyebabkan atau menimbulkan perilaku tertentu, dan memberi arah dan ketahanan (persistence) pada tingkah laku tersebut. Berdasarkan rumusan tersebut motif merupakan faktor dinamis, penyebab seseorang melakukan perbuatan.

Menurut Fox (1993), Motivasi merupakan konsep hipotesis yang tidak secara langsung dapat diamati yang dapat diamati adalah perilaku sesudahnya. Istilah motivasi sendiri berasal dari bahasa latin yaitu movere yang artinya gerak. Sedangkan Pintrich dan Schunk (1996) mengartikan Motivasi sebagai Kondisi psikologis (internal states) yang menimbulkan, mengarahkan dan mempertahankan tingkah laku tertentu.

Motivasi pada individu sangat penting karena motivasi yang dimiliki akan mempengaruhi perilaku seseorang termasuk dalam kegiatan belajarnya. Tinggi rendah motivasi yang dimiliki seseorang mempengaruhi timbulnya keinginan untuk belajar dan banyaknya materi yang akan dipelajari karena motivasi inilah yang memberi kekuatan dan arah pada tingkah laku yang ditampilkan individu (Atkinson, 1964).

Dalam belajar, motivasi menjadi penting agar setiap siswa agar dapat berhasil dalam mencapai sesuatu sesuai yang diharapkan. Dalam berbagai motivasi belajar dikenal dua sudut pandang motivasi, yaitu Motivasi Intrinsik yang berasal dari dalam pribadi dan Motivasi Ektrinsik yang berasal dari luar diri.

Motivasi Intrinsik dan Motivasi Ekstrinsik 
Menurut Huffman, Vernoy \&Vernoy (1997), Motivasi Intrinsik adalah "the desire to perform an act for its own sake", yaitu orang dengan motivasi belajar intrinsik tidak membutuhkan hadiah atau hukuman untuk membuat mereka belajar karena aktivitas belajar itu sendiri sudah menguntungkan, karena mereka menikmati tugasnya atau perasaan pencapaian prestasi yang diperolehnya (Wolfok, 1993).

Sedangkan motivasi ekstrinsik adalah: "The desire to perform an act because of external reward or avoidance of punishment". Ciri dari motivasi ekstrinsik dalam belajar adalah aktivitas belajar dimulai atau diteruskan berdasarkan kebutuhan dan dorongan yang tidak secara mutlak berkaitan dengan aktivitas belajar sendiri. (Winkel, 1996). Orang dengan motivasi belajar ekstrinsik, tidak terlalu tertarik pada aktivitas itu sendiri semata melainkan hanya peduli pada apa yang dapat diperoleh (keuntungan) dari aktivitas itu (Wolfok, 1993).

\section{- Motivasi Intrinsik}

Jika Motivasi Intrinsik adalah lebih cenderung kepada sebuah kesadaran pribadi terhadap sebuah tanggungjawab dan kewajiban, maka perasaan terhadap sebuah pencapaian penyelesaian tanggungjawab menjadi sebuah prestasi adalah sebuah dorongan yang cukup ekslusif baik pada sebagian siswa yang hidup dalam kecukupan maupun bagi sebagian siswa yang terpaksa hidup dalam keterbatasan.

Keduanya tentunya memiliki dorongan eksternal masing-masing sesuai dengan keinginan dan kebutuhannya. Motivasi Intrinsik sebagai dorongan internal dari dalam pribadi sebagai bentuk dari tanggungjawab hanya bisa tumbuh dari pribadi dengan mental dengan disiplin yang kuat dan kesadaran yang tinggi.

Namun menurut Winkel (1996), pada siswa yang telah mencapai sekolah tingkat menengah atas / umum. Biasanya para orangtua mengharapkan munculnya bentuk motivasi intrinsik lebih dominan dari pada motivasi intrinsik. Karena pada tahap ini dianggap siswa sudah mampu menyadari pentingnya belajar bagi masa depan dan kemajuannya sendiri.

\section{- Motivasi Ekstrinsik}

Menurut Winkel bentuk motivasi ekstrinsik dalam belajar biasanya adalah Belajar demi menghindari hukuman yang diancamkan, belajar demi memperoleh hadiah yang dijanjikan, belajar demi meningkatkan gengsi sosial, belajar demi memperoleh pujian dari orang yang penting dan belajar demi memenuhi tuntutan jabatan yang ingin dipegang atau untuk memenuhi persyaratan kenaikan jenjang.

Dalam belajar diperlukan motivasi yang cukup nyata dari hanya sekedar menikmati kewajiban menunaikan tugas atau perasaan berhasil dalam mencapai sebuah prestasi, kecuali pada karakterkarakter individu tertentu yang memang memiliki kesadaran dan kemampuan yang diatas rata-rata siswa. Dengan kata lain siswa yang hanya memiliki motivasi intrinsik adalah kasuistik pada siswa tertentu saja yang jumlahnya sangat sedikit.

Terlebih dalam masa Pembelajaran dari Rumah membuat rata-rata siswa menjadi terlanjur memiliki kenyamanan longgarnya waktu dalam melaksanakan tugas dan kewajibannya, apalagi ketika sudah tenggelam dalam keasyikan 
bermain game pada gadgetnya masing-masing ditambah dengan berkurangnya ketat pengawasan orangtua terhadap waktu bermain, istirahat dan belajarnya karena hilangnya waktu sekolah dari keseharian siswa.

\section{METODE PENELITIAN}

\section{A. Metode Penelitian}

Pelaksanaan penelitian Efektivitas Komunikasi Virtual Pembelajaran Daring dalam Masa PSBB dengan studi kasus Pembelajaran Jarak Jauh Siswa SMK Negeri 2 Banjarmasin penulis menggunakan metode penelitian Penelitian Lapangan (Field Research) dengan menggali data di lapangan untuk memperoleh data dan informasi.

\section{B. Tipe Penelitian}

Jenis penelitian menggunakan penelitian kualitatif yaitu jenis penelitian yang mengarah pada penelusuran tentang sosial yang berfokus pada mutu dan kualitas dari objek penelitian yaitu fakta-fakta dan fenomena yang terjadi di lapangan, dengan tujuan mendapatkan wawasan dari objek tersebut. Teknik yang digunakan dalam jenis penelitian ini menggunakan metode wawancara terstruktur dan observasi yang caranya disesuaikan dengan situasi PSBB yang sedang berlaku ketika sedang terjadi penelitian.

Dengan fokus penelitian yang ditekankan pada fakta lapangan mengenai wawasan dan pengetahuan baik dari siswa dan guru pengajar mengenai metode pembelajaran jarak jauh dan kualitas teknik pengajaran dari materi itu sendiri untuk memperoleh pemahaman tentang alasan yang mendasari, opini, dan motivasi dari kedua belah pihak sebagai unsur dari proses pembelajaran.

\section{Pendekatan Penelitian}

Pendekatan penelitian diterapkan dalam bentuk deskriptif yang menguraikan sifat dan keadaan dari objek penelitian, sehingga pengumpulan data ditujukan untuk dapat menguraikan fakta yang menyeluruh dan spesifik menurut permasalahan yang menjadi objek penelitian. Penelitian Kualitatif tujuannya adalah mengumpulkan fakta dan menguraikannya secara menyeluruh dan teliti sesuai dengan persoalan yang akan dipecahkan. (Rakhmat : 2004).

\section{Teknik Pengumpulan Data}

Pengumpulan data penelitian Efektivitas Komunikasi Virtual Pembelajaran Daring dalam Masa PSBB dengan studi kasus Pembelajaran Jarak Jauh Siswa SMK Negeri 2 Banjarmasin dilakukan dengan mengambil dari data primer dan sekunder yang dikumpulkan dengan cara :

a) Data Primer diambil langsung dari responden narasumber dengan menggunakan metode wawancara dengan daftar pertanyaan yang sudah disiapkan berbentuk pertanyaan terstruktur dan terbuka sehingga narasumber dapat dengan bebas menyampaikan pendapatnya secara mendalam sebagai tanggapan dari pertanyaan yang diajukan.

b) Data Sekunder diambil melalui wawancara kepada para guru pengajar dan observasi sebagai konfirmasi pada tempat penelitian mengenai data lainlain yang terkait dengan objek masalah penelitian.

\section{E. Lokasi Penelitian dan Waktu Penelitian}

Penelitian ini dilakukan di SMK Negeri 2 Banjarmasin yang 
melaksanakan sistem pembelajaran jarak jauh (PJJ) dalam jaringan atau Daring yang membebaskan teknik pelaksanaan lapangannya kepada para guru pengajar dengan bebagai pilihan sistem, baik itu PJJ Daring secara Sistem Berbasis Video atau pun Sistem PJJ Berbasis Data, dan baik itu secara serentak (Sinkron) atau pun tidak serentak (Asinkron).

Waktu pelaksanaan penelitian dilakukan dalam masa pembelakuan Pembatasan Sosial Berskala Besar sehingga dilaksanakan pada waktu yang fleksibel tergantung dengan jadwal masuk guru yang disusun secara bergiliran agar tidak terjadi penumpukan orang dalam satu ruang dalam satu waktu.

\section{F. Populasi dan Sampel}

Populasi adalah jumlah total dari seluruh unit atau elemen dari objek penelitian dilakukan. Sedangkan Sampel adalah bagian kecil dari keseluruhan objek penelitian yang dianggap mewakili presentasi populasi. Gregory secara lebih tajam mengartikan populasi sebagai keseluruhan objek yang relevan dengan masalah yang diteliti (Djailani, 1998: 107). Sampel adalah sebagian dari populasi yang karakteristiknya hendak diteliti (Djarwanto, 1994: 43).

\section{a. Populasi}

Populasi dalam penelitian kualitatif ini adalah Siswa Sekolah Menengah Kejuruan Negeri (SMK)

2 Banjarmasin yang melaksanakan pembelajaran mata pelajaran Produktif di Sekolah Menengah Kejuruan Negeri 2 Banjarmasin dengan Metode Pembelajaran Jarak Jauh secara Daring atau Dalam Jaringan.

\section{b. Sampel}

Pemilihan sampel yang digunakan dalam penelitian ini adalah siswa- siswi jurusan produksi dan siaran program televisi dan film yang merupakan bagian dari Sekolah Menengah Kejuruan Negeri (SMK) 2 Banjarmasin sebagai objek penelitian yang melakukan pembelajaran mata pelajaran produktif.

\section{G. Analisa Data}

Metode analisis data dalam penelitian kualitatif ini dilakukan dengan cara mengumpulkan, mengelompokkan dan memilah data hasil wawancara dari narasumber siswa jurusan produksi dan siaran program televisi dan film pada mata pelajaran produktif Sekolah Menengah Kejuruan Negeri (SMK) 2 Banjarmasin untuk dapat mendefinisikan fakta pola apa yang penting untuk dipelajari dan dapat disampaikan sebagai wawasan kepada orang lain. Sesuai menurut Bogdan dan Biglen, analisis data kualitatif adalah upaya yang dilakukan dengan jalan bekerja dengan data, mengorganisasikan data, memilahmilahnya menjadi satuan yang dapat dikelola, mensitetiskan, mencari dan menemukan pola apa yang penting dan apa yang dipelajari dan memutuskan apa yang dapat diceritakan kepada orang lain.

\section{HASIL PENELITIAN}

1. Efektivitas Komunikasi Virtual Pembelajaran Daring bagi siswa mapel Produktif :

Mengingat ciri-ciri dari pembelajaran efektif diantaranya adalah; Aktif, Kompleks, Perlakuan berbeda sesuai individu siswa dan perlakuan berbeda sesuai konteks belajar. Dan mengingat kriteria pembelajaran efektif adalah ; Kecermatan penguasaan materi, Kecepatan unjuk kerja, Tingkat alih belajar dan Tingkat retensi yang tinggi (Reigeluth \& Merril, 1989). 
Maka pembuktian efektivitas komunikasi virtual Pembelajaran Daring bagi siswa yang mengikuti proses pembelajaran dalam jaringan secara online yang diberikan oleh guru mata pelajaran produktif yang biasanya dilaksanakan secara praktek di lapangan. Bahwa sebagian besar atau lebih banyak siswa yang merasakan pengaruh kurang efektif dari sistem pembelajaran jarak jauh Daring dengan komunikasi virtual. Hal tersebut dianalisa terjadi dipengaruhi karena berbagai faktor, baik dari faktor teknis fasilitas, konsep cara pembelajaran dan motivasi, yaitu ;

a. Pengaruh Faktor Fasilitas / Sarana : yaitu adanya peralatan kebutuhan Pembelajaran Jarak Jauh Daring secara Komunikasi Virtual berupa perangkat Smartphone, Paket Kuota Data Internet dalam jumlah yang cukup dan Jaringan Internet yang terjangkau dan stabil untuk memastikan pembelajaran metode Daring berjalan dengan baik dan lancar.

b. Pengaruh Faktor Konsep Cara Pembelajaran : yaitu adanya persiapan konsep pembelajaran dari Guru pengajar yang sesuai dengan Pembelajaran Jarak Jauh Daring secara Komunikasi Virtual agar bisa memanfaatkan fitur teknologi secara tepat, efektif dan efisien. Sehingga fitur teknologi dapat digunakan secara optimal untuk dapat meningkatkan kemampuan kreatifitas siswa walau pun belajar dari rumah saja.

c. Pengaruh Faktor Motivasi : yaitu adanya dorongan kemauan atau motivasi baik secara intrinsik yaitu sebuah kesadaran pribadi terhadap sebuah tanggungjawab dan kewajiban, sehingga muncul perasaan untuk dapat melakukan pencapaian dalam menyelesaikan tanggungjawab sebagai pelajar.
Maupun secara ekstrinsik yaitu adalah dorongan ikut serta dalam belajar hanya untuk menghindari sebab-akibat sanksi atau demi memperoleh keinginan, tujuan atau cita-cita tertentu.

2. Kendala dan Permasalahan dalam Komunikasi Virtual Pembelajaran Daring :

Komunikasi Virtual yang dilaksanakan oleh guru sekolah menengah kejuruan untuk Pembelajaran Jarak Jauh Daring kepada siswanya dari rumah masingmasing dengan menggunakan teknologi komunikasi jarak jauh baik secara serentak dan tidak serentak, dirasakan adanya kendala dan permasalahan dalam pelaksanaannya khususnya pada mata pelajaran produktif program produksi dan siaran televisi yang harus dilaksanakan secara praktek lapangan. Kendala dan Permasalahan yang muncul ditelusuri terjadi dari Internal dan Eksternal, baik pada objek penelitian siswa maupun pada guru sebagai pelaksana pembelajaran yang berdasarkan pada penemuan :

a. Kendala Internal berupa rendahnya motivasi untuk mengikuti pembelajaran Daring dan kurang disiplin mengakibatkan permasalahan kurang jumlah siswa yang ikut serta dalam pembelajaran jarak jauh Daring, baik itu dalam bentuk interaksi komunikasi secara virtual maupun interaksi data saja. Sehingga penilaian oleh guru terhadap siswa menjadi kurang lengkap dalam proses pembelajaran yang seharusnya dapat dilaksanakan secara optimal jika seluruh siswa peserta didik yang mengikuti secara lengkap.

Analisa data menyebutkan hal tersebut terjadi karena sebagian besar siswa pembelajaran jarak jauh memberikan peluang bagi 
siswa untuk mengulur dan memperlakukan waktu rutinitas siswa secara bebas tanpa tekanan secara langsung dari sekolah yang biasanya dapat berupa sanksi jika melakukan tindakan tidak disiplin.

b. Kendala Eksternal berupa kurangnya sarana atau fasilitas alat dan bahan untuk melaksanakan proses pembelajaran jarak jauh Daring secara Komunikasi Virtual yang membutuhkan Smartphone dengan teknologi yang memadai dan Kuota Paket Data Internet yang mencukupi yang mengakibatkan permasalahan kurang optimalnya pemahaman materi yang bisa didapatkan oleh siswa peserta didik karena terganggunya kelancaran jaringan ketika proses pembelajaran daring komunikasi virtual sedang berjalan.

Serta kurangnya penyampaian materi contoh peragaan yang dibutuhkan oleh siswa untuk dapat memahami materi pelajaran produktif dengan baik, yang dalam hal bidang keahlian Produksi dan Siaran Program Televisi dan Film materi praktek produksi berupa shooting di lapangan yang membutuhkan objek di dalam dan di luar ruangan dengan perangkat kamera khusus.

3. Pola Pembelajaran Daring secara Komunikasi Virtual pada siswa SMKN 2 Banjarmasin :

Pola-pola Pembelajaran secara Komunikasi Virtual yang dilaksanakan oleh guru SMKN 2 Banjarmasin kejuruan kepada siswa dalam proses pembelajaran Daring mata pelajaran produktif Produksi dan Siaran Program Televisi dan Film, yang semestinya dapat dilaksanakan oleh guru dan siswa secara kreatif dengan kelonggaran waktu dan aturan, ditemukan fakta terdapat pola pembelajaran biasa atau konvensional dalam bentuk ;

a. Ceramah ; adalah sebuah metode penyampaian materi dalam proses pembelajaran yang menggunakan cara memaparkan langsung secara lisan kepada peserta didik mengenai materi pelajaran yang diajarkan secara detail dan jelas yang dapat menggunakan materi presentasi sebagai alat bantunya.

b. Tanya Jawab ; adalah sebuah metode pembelajaran yang meminta atau mengajak siswa peserta didik untuk menagajukan pertanyaan untuk mendapatkan penjelasan dari jawaban guru pengajar tentang materi pelajaran yang tidak atau kurang difahami yang dapat diajukan baik secara tertulis atau langsung secara lisan.

c. Penugasan ; adalah metode pembelajaran yang menginstruksikan atau menyuruh siswa peserta didik untuk melakukan sesuatu berkaitan dengan materi pelajaran disampaikan oleh guru pengajar yang bertujuan untuk agar siswa memperoleh pemahaman yang tepat, mencoba mempraktekkan dan bisa melakukan pembuktian sendiri mengenai materi pelajaran yang telah disampaikan.

\section{Kesimpulan}

1. Tidak berpengaruh secara efektif dalam penelitian Efektivitas Komunikasi Virtual Pembelajaran Daring bagi siswa yang mengikuti proses pembelajaran dalam jaringan atau Daring atau online yang diberikan oleh guru pengajar pada Sekolah Menengah Kejuruan (SMK) Negeri 2 Banjarmasin terhadap pada mata pelajaran produktif Produksi dan Siaran Program Televisi dan Film, yang biasanya dilaksanakan secara 
praktek kreatif baik dalam kelas maupun di lapangan.

2. Terdapat Kendala dan Permasalahan dalam Komunikasi Virtual Pembelajaran Daring yang dilaksanakan oleh guru pengajar Sekolah Menengah Kejuruan (SMK) Negeri 2 Banjarmasin kepada siswanya menggunakan teknologi komunikasi virtual jarak jauh baik berupa kurangnya sarana atau fasilitas berupa Smartphone dengan teknologi yang memadai dan Kuota Paket Data Internet yang cukup dari sisi siswa disamping rendahnya motivasi dan kurang disiplin dalam mengikuti pembelajaran daring mengakibatkan penilaian oleh guru terhadap siswa menjadi kurang lengkap dan tidak optimal.

Dari sisi Guru Pengajar kurangnya persiapan konsep pembelajaran dalam penyampaian materi dirasakan siswa dalam bentuk kurangnya contoh peragaan sehingga sulit untuk dapat memahami materi pelajaran produktif dengan baik.

3. Tidak teridentifikasi Pola-pola yang khusus dalam pola pembelajaran secara Komunikasi Virtual yang dilaksanakan oleh guru pengajar produktif Sekolah Menengah Kejuruan (SMK) Negeri 2 Banjarmasin kepada siswa mata pelajaran produktif Produksi dan Siaran Program Televisi dan Film, dalam proses pembelajaran Daring yang semestinya dapat dilaksanakan oleh guru dan siswa secara kreatif dalam kelonggaran waktu dan aturan terkait pemanfaatan teknologi komunikasi.

\section{REFERENSI}

Arikunto. 2008. Penelitian Tindakan Kelas. Jakarta : PT.Bumi Aksara

Nasrullah Rulli. 2015. Media Sosial Perspektif Budaya dan
Sosioteknologi. Bandung : Simbiosa Rekatama Media

Emzir. 2012. Metodologi Penelitian Kualitatif Analisis Data. Jakarta: Rajagrafindo Persada

Gulo, W. 2008. Strategi Belajar Mengajar. Penerbit: Grasindo

Nurudin. 2017. Perkembangan Teknologi Komunikasi. Jakarta: PT. Raja Grafindo Persada

Astim, Riyanto. 2003. Proses Belajar Mengajar Efektif di Perguruan Tinggi. Bandung: Yapemdo.

Valentina, Elvi, \& Wulan Purnama Sari. 2018. Studi Komunikasi Verbal dan Non Verbal Game Mobile Legends: Bang Bang. Jurnal Koneksi, 2(2), 300-306

R. Fathurrohman, A. Halim, K. Imawan. 2017. Pengaruh Komunikasi Virtual terhadap Komunikasi Interpersonal di Kalangan Game Online di Aranet Plumbon, Jurnal Signal Unswagati Cirebon.

Caroline Vinci Wijaya, Sinta Paramita. 2019. Konunikasi Virtual dalam Game Online (Studi Kasus dalam Game Mobile Legends), Koneksi EISSN 2598-0785 Vol. 3, No. 1.

Mada Sutapa. Membangun Komunikasi Efektif di Sekolah. Jurnal Manajemen Pendidikan, No. 02/Th II/Oktober/2006.

Tutut Handayani. 2011. Membangun Komunikasi efektif untuk Meningkatkan Kualitas dalam Proses Belajar Mengajar. TA'DIB, Vol. XVI, No. 02.

Yusuf Bilfaqih \& M. Nur Qomarudin. 2015. Esensi Pengembangan Pembelajaran Daring Panduan Berstandar Pengembangan Pembelajaran Daring untuk Pendidikan dan Pelatihan. Yogyakarta : Deepublish Publisher 